\section{A CASE OF COLLOID CARCINOMA OF THE SKIN}

\author{
A. BAMBERGER, B.S., M.D. \\ Resident Physiclan, Cook County Hospltal
} CIIICAGO

I report this case, first, because of its rare occurrence, as I am unable to find a similar condition reported in literature, and secondly because it emphasizes the impor'tance of laboratory work in cases of obscure diagnosis.

History.-Miss C. G., unmarried, aged 35, a clerk, entered my service at the Cook County Hospital, June 8, 1910. She had always lived in Chicago and was apparently of good laab. its. Menstruation began at 14 ycars, was regular and of the twenty-eight-day type.

Present Illness.-Tho patient stated that two weeks before entering the hospital a blister appenred on the lower third of the right leg and that after a few days it openel, and in uleer followed, for which she sought treatment. She denied having injured the leg or having applied any drug locally. With the exception of the ulcer she said she was in good health.

Past History.--Slre was well up to the present illness, except that her legs occasionally swelled, which condition a physicinu told her was due to nephritis. She had diseases of childhood and maluria ten years ago, but denied typhoid and all vencreal infections. Family history was negative, except that the patient's mother died of hent disease.

Examination.--The patient was an obese white woman, quite nervous, but apparently having no pain; no cyanosis or ieterus. The pupils were equal, rencted to light and accommodation; the mouth was negative, except for a few decayed teeth; there was no thyroid enlargement. The lungs were negative. The heart showed no enlargement; tones strong, regular, no murmurs. There were no ascites, no nbdominal masses, no tenderness on palpation. 'The liver was not enlarged; the spleen not palpable. The lower half of the right leg was edematous. About 2 inches above the ankle was a superficial, irregularly shaped nlcer about 2 inches in diameter. 'The parts surrounding the ulcer were inflamed and tender. The femoral glands of the right leg were moderately enlarged; there was a slight varicosity of veins of both legs; pulsation of posterior tibial and dorsalis peclis was less marked on the right than on the left leg. The uterus was in good position and not tender; there were no masses or tenderness in pelvis. Knee-jerks were present; Romberg and Bubinski absent. 'The urine was clear, anber, specific gravity 1020 , acid, no albumin, sugar, casts, leukocytes or red-cells. Blood examination sliowed 15,000 leuliceytes; no malarial parasites.

Course of the Disease.-On first examination I thought the condition was a dermatitis with infection and ulceration, and accordingly applied hot dressings, which failed to allevinte the symptoms. During the first three weeks in the hospitnl the patient ran an irregular temperature, ranging from 99 to $101 \mathrm{k}$., with no special evening rise. The ulcer gradually extended until it involved the entire anterior third of the leg and laid bare the tibin. It was very foul and sloughing. On the ninth day after admittance a bluish discoloration of the toes appeured which gradually increased in intensity and extension until there was a well demarcated gangrene of the entire foot and lower third of the leg on the twonty-second day. The leg was then amputated just below the knee. During the padient's entire stay in the hospital she had a severe diarrhea of greenish, liquill stools, containing small amounts of blool, but no parasites, and also continually lost weight. After the operation the putient grew steadily worse, the diarrhea becom. ing uneontrollable and the emaciation being very rapid. 'Jhree weeks after the operation she became irrational and very weak, and three days later, on the forty-sixth day after admittance, diek. I was uncertuin as to the cause of death and as no post-mortem examination wis permitted I made the tentative diagnosis of tuberculous enteritis.
Pathologic Finding.-At the time of amputation I excised a piece of the involved tissue for examination, which the hospital patlologist diagnosed as colloid carcinoma.

As colloid carcinomas occul most fiequently in the intestines it is most probable that the patient had a colloid carcinoma of the intestines with a secondary growth in the skin.

\section{'THE PATHOLOGY OF JOJN'T' TUBERCULOSIS : TUBERCULOUS SINUSES}

LJEONARD W. ELY, ṂI.D. DENTER

In numerous articles in the past 1 have called attention to the inuortance of avoinling secomblary infection of the walls of tubereulous sinuses and alscesses by the germs of suppuration, and have pointerl out the danger the jatient incurs if this secondary infection take place. In this I have followed the teachings of other's and my own experience, an experience gathered in treating many rasses of joint tuberculosis. On the other hand, the custom of opening, scraping and packing tuberenlous abscesses is still widespreat, and those who practice it do so either from ignorance or beciltse their experience teaches them that it is correct. Sow, the experience of one man may be said to be as gooil as that of another, and until we can bring proof to sustain us we shall hardly convince our opponents. A very suggestive case of tarsal tuberculosis has recently furnished us with additional evilence of the truth of our contentions, and I shall quote it at length. Before doing so, however, I wish to call attention to one or two points in the pathology of joint tubereulosis.

Pure tuberculosis does not, possibly with very rare cxceptions, attack ordinary connective tissues of low grade of organization. 'They must contain some peculiar cellular elements in addition.

The red or cellular marrow of bone and the cellular synovial membrane, tendon sheaths, lympl nodes, epithelial structures, etc., are vulnerable; but cartilage, ligranents, fatty or yellow marrow, filurous comnective tissue, etc., escaje direct infection. If, howerer, a secondary infection by pus germs be added, tissues that were immune before, now are open to attack.' An ordinary tuberculous abscess, starting from a focus in a bone, making its way toward the surface along the fascial planes, travels along a path of ordinary fibrous tissue which is not open to attack. So long as these abscesses remain uninfected the patient does not suffer from constitutional involvement nor from other srmptoms exeept possibly those due to pressure. If a secondary infection be added the entire picture is changed, and forthwith the constitutional symptoms of pain, fever, etc., become prominent, the clanger to the patient is greatly increased and his chances for recovery are seriously impaired.

What is the reason for this? Why are these tracts once infected so difficult to heal? No matter how vigorous our method of drainage, their course is never that of a simple infected abscess. They may exist for years. One l'eason is that the secondary infection has changed what was a small localized tuberculous focus into a wjdespread tuberculous area, and has added a mixed infection. In an old tuberculous sinus tubercles may be seen under the microscope deep in the walls, inaccessible to any curette, but in an uninfected sinus no tuberculosis is present. In other words, the walls of an uninfected

1. Ely : Surg., Gynec., and Obst., Jujy, 1010. 
tuberculous sinus are not tuberculous; the walls of an infected tuberculous sinus are tuberculous. By permitting infection of a sinus with pus germs we are at the sume time infecting it with tuberculosis. This fact, though not new, is not generally lnown. The following (ase illustrates it:

'The patient was a man of forty-four years, a driver. He lud suffered from pain and disability of his right foot for twenty months, and these symptoms had increased to steh an extent that he was conpelled to go about on crutches. He had been treated with plaster of Paris and strapping. and had never had any open sinuses. Examination showed mod. erate swelling over the dorsum of the foot, and considerable sensitiveness to pressure. The foot was in eversion. The lungs were involved. The evidences of the disease were so small that the wisdom of an amputation was doubted, but. acting on the theory that tarsal tuberculosis in the adult seldom if ever is cured without an amputation, and especially in view of the patient's pulmonary disease, this operation was decided on and was performed at the Roosevelt Hospital. During the performuner of a Sime's amputation, the knife of the operator cut through a sinus on the dorsum of the foot, Jeading upward, but not communicating with the surface. lirom this sinus pus oozed.

By courtesy of the louse staff I secured the specimen. On dissection it was found that the comparatively mild symptom were caused by an extensive tarshl tuberculosis which had involved two of the tarsul joint cavilies with their ramilications, and the tulus, navicular and cuneiform bones. The eartilnges were roughened, mottled and eroded at their per. iphery. The synovial membrane was thickened and intlumed, and showed under the micros(n)e typical tuberculosis, but the walls of the sinus from this tuberculous lesion showed, not tubereulosis, but the ordinary evidences of inflammation--round cells, polymorphonuclears, edema, arterial thickening, dilated capillaries, etc.

If one will picture to himself this extensive bon tuberculosis penetrating the bones of the tarsus, covered up us it is by liganents ruming in every direction, with numerous tendons passing orel these, and with blood ressels and nerves alded. he will appreciate the utter absurdity of an attempt by a partial operation to eradicute under all these a distalse of whose extent he cannot possibly have any iden. Any other operation than an amputation would have been worse than useless.

440 Humboldt Street.

\section{Special Article}

\section{TYPHOID FEYER IN DETROIT}

\section{J3Y THE SPECFAL COMMISSIONER OF THE JOURNAT,}

The reports of the municijol bond of health show that in certain vears typhoid fever has prevaled in 1)etroit to an extent that must be called excessive. 'The denth-rates from this disease for $188 \%, 1888,1892,1893$ and 1907 are so high that they might well have been the occasion for grave concern to the inhabitunts of any modern civilized city. The facts are set forth in Tables 1,2 and 3 .

\section{NATURE OF THE AYALABLE STATISTIOS}

Other than these bare records of deaths, there is little to throw light on the extent, distribution and nge ineidence of typhoid fever in Detroit. The first report of the health department was published in 1882 ; so lite as 1894 we find 83 deaths recorded under the head of "felmis," and in n footnote these are said to include: "Celoris intermittens 8 , perniciosa 1 , puerperalis (!) 10 , remittens 4 , typhoides 64 , typho-malaria 6 :" it was not till 1904 that typhoid ferer was alded to the list of diseases that must be reported to the health officer. Even now it is plain that only a small proportion of the typhoid fever cases are regularly reported to the anthorities. In 1905-6, 70 deaths and only 87 cases were reported. It may be recorded in passing that the system of recording vital statistics on the basis of the fiscal year (July 1-July 1) rather than the alendar year does not facilitute comparison with conditions in other cities.

It must not be supposed that Jetroit is peculiar in most of the practices above mentioned. Intil recently few American cities have has a satisfactory system of nomenclature, and certainly very few have at the present time any adequate recold of typlioid fever cases. Detroit can hardly be said to be much different in this respect from the average American city of its class.

An exception must here be noted to the aforesaid meagerness of record. One particularly severe outbreak

\begin{tabular}{|c|c|c|c|c|}
\hline ABLE & 1.-TYIIIOFD & DEATH-RAT & 'S, DE'LIROI'l, & , 1886-1900 \\
\hline · & lous. & Population.* & .No. Denths. & $\begin{array}{c}\text { Deaths per } \\
100,000 \text { polv.t }\end{array}$ \\
\hline 1880 & $\ldots \ldots$ & 170,061 & $6 \tau$ & 39.4 \\
\hline 1887 & $\ldots \ldots$ & 174,015 & 116 & 64.9 \\
\hline 1888 & $\ldots \ldots$ & 187.086 & 81 & 45.0 \\
\hline 1880 & $\ldots \ldots$ & 196,922 & Bi & 30.5 \\
\hline 1890 & $\ldots \ldots$ & 205.870 & 39 & 19.0 \\
\hline 1801 & $\ldots \ldots$ & 213,850 & 73 & 34.1 \\
\hline 1892 & $\ldots \ldots$ & 201.842 & 208 & 93.8 \\
\hline 1893 & $\ldots \ldots$ & 200.825 & 176 & 42.2 \\
\hline 1894 & $\ldots \ldots$ & 237.808 & 67 & 28.2 \\
\hline 1896 & $\ldots \ldots$ & 245.700 & 61 & 24.2 \\
\hline 1894 & $\ldots \ldots$ & 253,773 & 57 & 22.5 \\
\hline 1807 & $\ldots \ldots$ & 261.750 & 38 & 14.5 \\
\hline 1808 & $\ldots \ldots$ & 269,730 & 58 & 21.5 \\
\hline 1890 & $\ldots \ldots$ & 277.722 & 35 & 12.6 \\
\hline 1000 & $\ldots \ldots$ & 285.704 & 50 & 17.5 \\
\hline 1001 & $\ldots \ldots$ & 303.710 & 58 & 10.1 \\
\hline 1002 & $\ldots \ldots$ & 321,716 & 60 & 18.6 \\
\hline 3003 & $\ldots \ldots$ & $339,7 \div 2$ & 53 & 15.6 \\
\hline 1804 & $\ldots \ldots$ & 357,728 & 38 & 16.2 \\
\hline 1005 & $\ldots \ldots$ & 375.735 & 63 & 16.7 \\
\hline 1000 & $\ldots \ldots$ & 393,741 & 80 & 20.3 \\
\hline 1907 & $\ldots \ldots$ & 411,747 & 100 & 24.3 \\
\hline 1008 & $\ldots \ldots$ & 429.753 & 87 & 20.2 \\
\hline 1000 & $\ldots \ldots$ & 447.759 & 14 & 21.0 \\
\hline
\end{tabular}

- Population of $1880,1890,1900,1910$, U. S. Census. InteyvenIn "years calculated by "arithmeticul" method ('Twelfth Census (III. No. 135).

mant

7 inutes computed directly from populntions and typhoid deaths given in this paper.

TABLE 2.-AVIEAGE TYPIHOID IDATH-RATES BY FIVE-YEAI PERIOIS

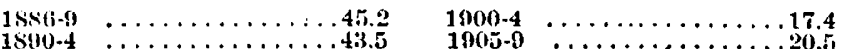

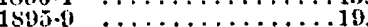

of typhoid fever-in 1892-was made the object of special investigation by a competent observer, ${ }^{1}$ and his conclusions were published in a supplement to the annual report of the Michigan State Board of Health, 1898.

\section{THE CAUSE OF 'THJ: 1892 OUTBREAK}

'The extensive epidemic of the summer of 1892 carried the typhoid death-rate for that year to the highest figure known in the sanitary history of the city (93.8) and is one of the severest recorded in any American city during the last twenty-five years. Professor Williams' careful study of the distribution of the deaths and the age of the decedents, together with other data, led him to the belief that nothing but the public water-supply could be the general vehicle of infection. All the facts olstainable at the time pointed to this conclusion, and it is indeed difficult to explain so explosive an epidemic and one of such magnitude in any other way. The discussion that followed the reading of Professor Williams' paper in the sanitary convention at Detroit in December, 1897,

1. Galdner $\mathbf{S}$. Wlillans, at the time civll englneer to the Board of Wintel Commissionel's of Detrolt. 